\title{
Range contractions in the Critically Endangered Seychelles terrapins (Pelusios spp.)
}

\author{
J. Gerlach and L. Canning
}

\begin{abstract}
The status of the Seychelles endemic terrapins is reviewed based on field-surveys. Pelusios castanoides intergularis and $P$. subniger parietalis are confined to a small number of marshes and rivers. All the sites occupied are limited in area ( $<4.5$ ha) and under threat from drainage, predation and invasion by alien water plants. The smallest populations are unlikely to be viable in the long-term. Both species can be categorized as Critically Endangered using the IUCN Red List categories, with highly restricted ranges (2.89
\end{abstract}

\section{Introduction}

Three endemic terrapin taxa have been recorded from Seychelles. Two of these, Pelusios subniger parietalis and $P$. castanoides intergularis, are subspecies of African species, whereas the third is an endemic species, $P$. seychellensis, closely related to $P$. castanoides. Both $P$. subniger and $P$. castanoides have been introduced to other island groups (Bour, 1983, 1984) but appear to be a natural component of the Seychelles fauna. Their presence in the islands is probably a result of colonization during the Wisconsin glacial period $(15,000$ years ago) when sea levels were some $120 \mathrm{~m}$ lower than at present (Taylor et al., 1979) and the submarine banks of the Seychelles plateau and Amirante banks would have provided a land chain from Africa and Madagascar. No other terrapin genera are native to the islands.

There is little information available on the distribution, population size or biology of terrapins in Seychelles. Pelusios seychellensis is known only from three specimens collected from an unknown locality in 1895 (Siebenrock, 1906; Bour, 1983, 1984) and one record attributed to this species in 1994 (Gerlach and Canning, 1996). Research into the status of $P$. seychellensis was recommended as a high priority in the 1989 Tortoise and Freshwater Turtle Action Plan (Swingland \& Klemens, 1989). No further specimens have been located and its taxonomic status is unclear.

Both $P$. subniger and $P$. castanoides appear to be widely distributed in Seychelles (Fig. 1), with popula-

\footnotetext{
J. Gerlach (Corresponding author) and L. Canning 133 Cherry Hinton Road, Cambridge CB1 7BX, UK. E-mail: jstgerlach@aol.com

Revised manuscript accepted for publication 11 July 2001
}

and 6.02 ha for $P$. castanoides and P. stuniger, respectively) that have decreased by over 50 per cent in recent years. Conservation of these species requires both the protection of wetland habitats and the establishment of new populations in protected areas. A captive breeding programme has been established with the aim of reintroducing juveniles into secure reserves. The endemic species $P$. seychellensis may be extinct.

Keywords Marsh, Pelusios, river, Seychelles, terrapin.

tions in several lowland rivers and marshes (Bour, 1983). There are also isolated reports from mid-altitude suburban areas (Le Niol and La Misère; Gerlach \& Canning, 1996). Pelusios castanoides has been recorded from the islands of Mahé, Cerf, Praslin and La Digue, $P$. subniger from Mahé, Cerf, Praslin, La Digue and Fregate, and unspecified taxa on St Anne, Silhouette, Cousin, Aride and Curieuse (Bour, 1983; Gerlach, 1997a). There are no published records from the other islands that have, or had, marshy areas (North, Cousine and Grande Soeur).

The aim of this paper is to review the status of Seychelles terrapins based on studies that we carried out in 1996-1999, and to highlight conservation measures required for their survival.

\section{Methods}

The largest areas of marsh habitat, which were expected to support the most important terrapin populations, occurred on the larger islands of Mahé, Silhouette, Praslin and La Digue. We therefore concentrated our work on these islands, but we also collected historical and recent records from smaller islands. From $1: 10,000$ survey maps we identified 59 marsh sites and estimated their areas (Table 1). Trapping studies were carried out at 10 sites on Mahé, Praslin and La Digue (Table 2), selected for accessibility, specific habitat features or because the presence of terrapins had been reported. An additional 18 sites were examined but trapping was not carried out, because either there were no suitable trap sites or problems with access would have prevented the repeat visits required for trapping. The remaining 31 small marshes were not investigated and terrapin 


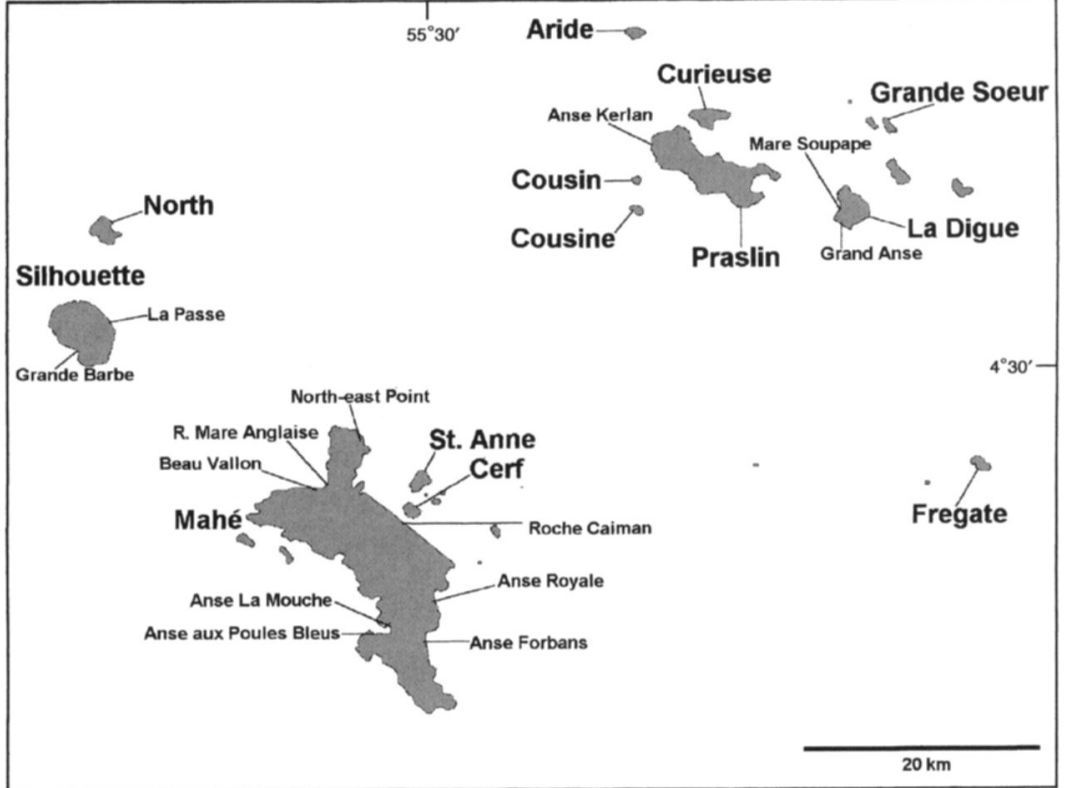

Fig. 1 The islands of Seychelles, with marshes in which terrapius have been trapped or observed. presence was evaluated from information provided by local residents.

In order to estimate population sizes a mark-recapture trapping system was used with baited funnel traps (Legler, 1960). Tinned tuna in soya oil was used as bait for most of the traps, although a small number were baited with coconut, snails or chicken entrails to investigate the effects of different baits on trap success. Terrapins were only caught in fish-baited traps and so fish was used exclusively after the first week. Ten traps were widely distributed within each marsh, and were set approximately $5 \mathrm{~m}$ apart along river banks or margins of pools. The captured terrapins were marked with individual marginal notches, using a hand-saw, to allow identification on subsequent recapture. These shallow ( $2 \mathrm{~mm}$ ) notches have been used for many years in chelonian marking and have no effect on health or survival (Cagle, 1939).

The trapped terrapins were sexed and examined for any obvious signs of damage, and all taxonomically useful external characteristics (Bour, 1983) were recorded to the nearest millimetre. Females have short tails, reaching forward to the suture between the 11 th and 12 th marginals, and a concave anal notch; whereas males have longer tails, reaching to the 10-11th marginals, and a straight sided anal notch. Individuals over $10 \mathrm{~cm}$ straight carapace length could be sexed in this way, whereas those below this size could not be sexed with confidence and were categorized as 'juveniles'. In addition, privately kept captive terrapins were examined.

Study sites were categorized as high altitude marsh ( $500 \mathrm{~m}$ above sea level), mid-high altitude river $(>200 \mathrm{~m}$ above sea level) or lowland habitat. The lowland habitats were further categorized as open (permanent woodland river or marsh containing Eleocharis or Typha reed-beds), seasonal (subject to annual drying out) or invaded (covered by water lettuce Pistia stratiotes). Any obvious pollution (e.g. rubbish and organic waste) was noted. The numbers of aquatic invertebrates were assessed in 31 marshes by counting all taxa in $10 \times 1 \mathrm{sq}$ m quadrats.

The study was undertaken during both dry (JulySeptember 1996, July 1997) and wet (January 1997, January 1998, January 1999) seasons. Numbers of trap days are given in Table 2. The initial period of trapping in 1996 was the most intensive; subsequent trapping was carried out opportunistically. These subsequent trapping periods concentrated on sites where terrapins were recorded in the initial period. Within the Beau Vallon - Rivière Mare Anglaise marsh system on Mahé a number of the initial trap sites were later found to be inappropriate (e.g. in exposed sites, saline or rapidly running water). These sites were not used again until January 1999 when all the trap positions in the marsh system were repeated, confirming the unsuitability of some for catching terrapins. Opportunities for trapping at Anse Kerlan on Praslin were more limited and trapping effort varied but was maintained at a minimum of 80 trap days per trapping period.

\section{Results}

We only discovered terrapins in lowland habitats (Table 1), with $P$. castanoides in woodland rivers and reed-beds and $P$. subniger in marshes. Relatively 


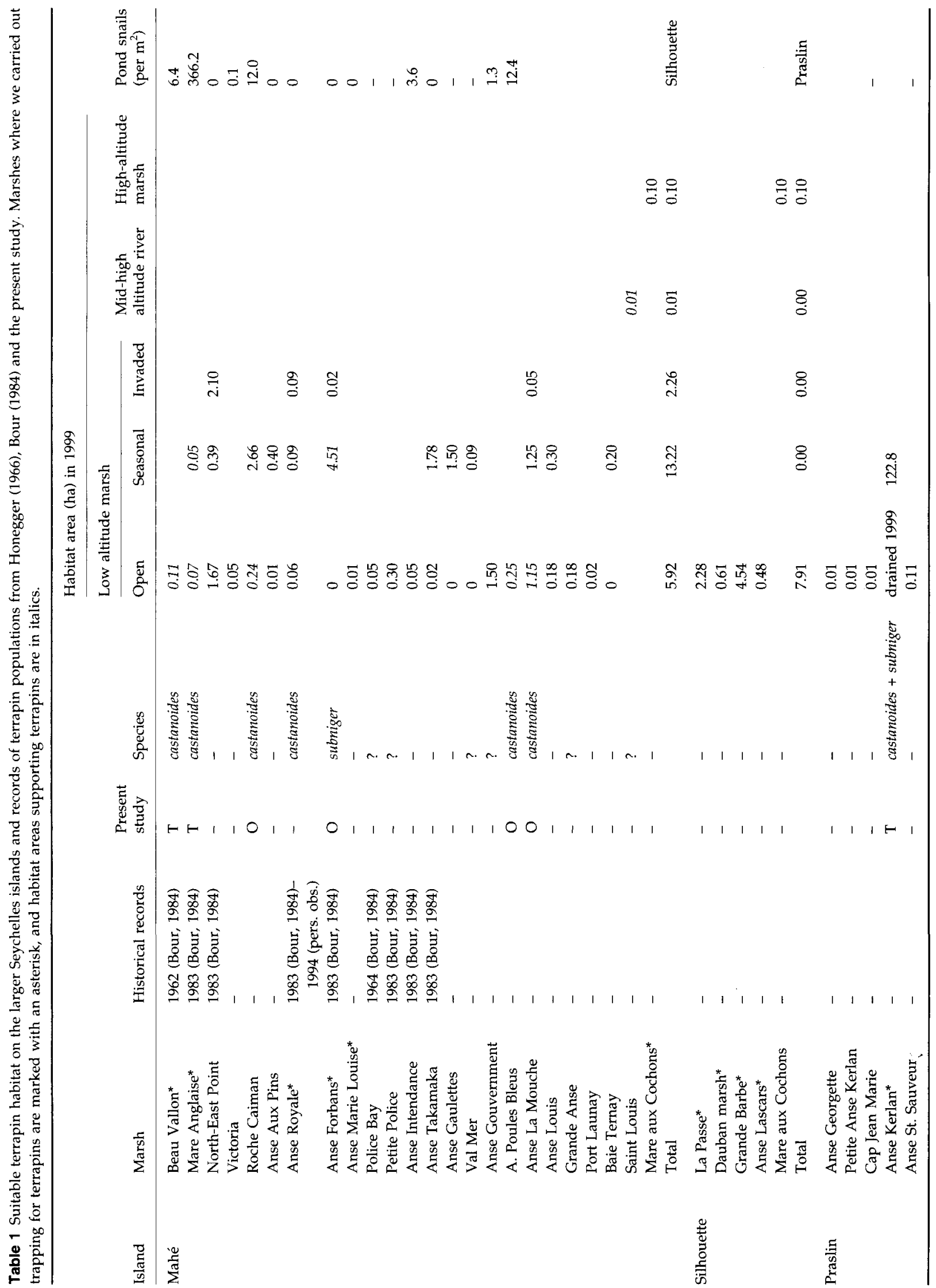

(c) $2001 \mathrm{FFI}$, Oryx, 35(4), 313-321 


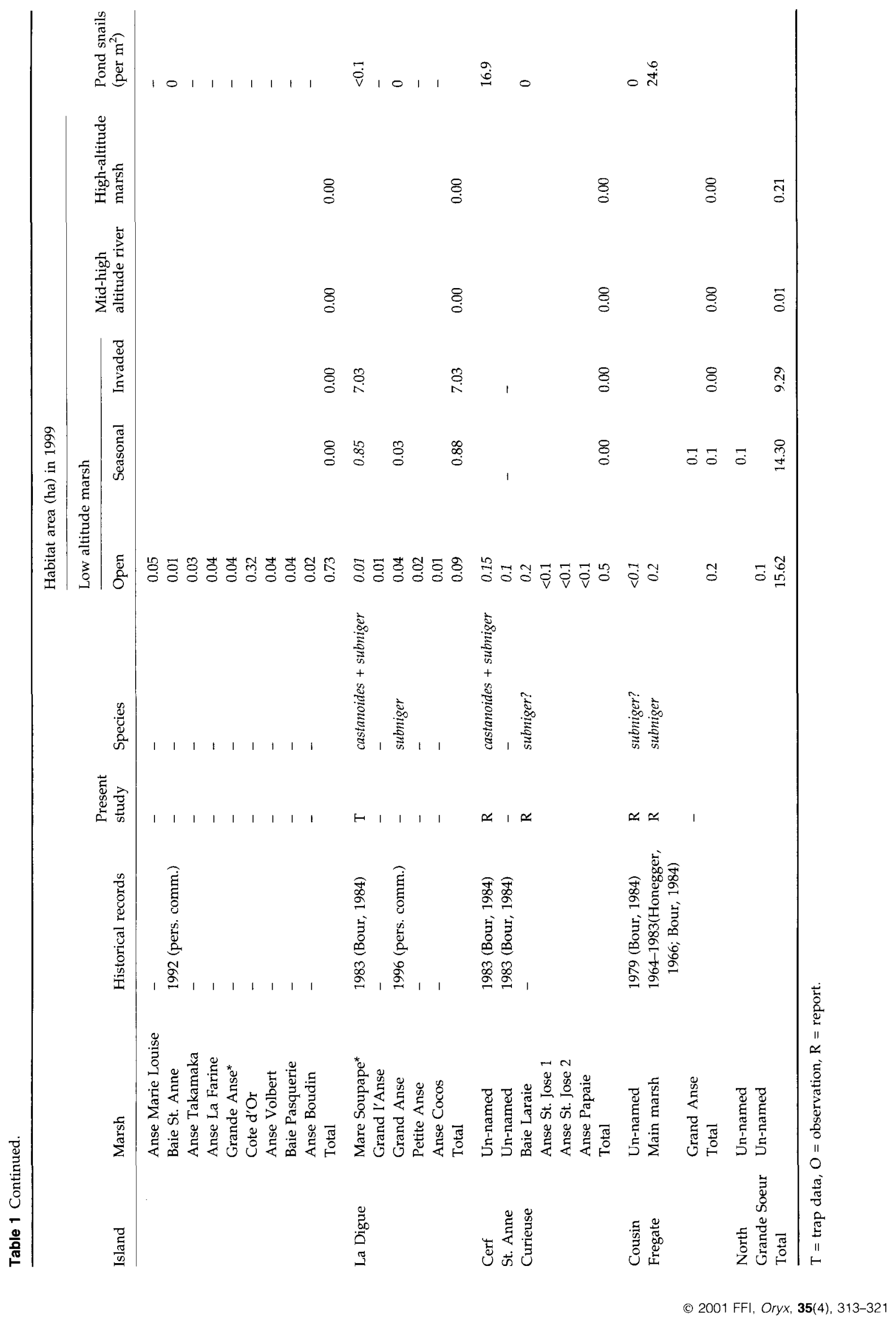




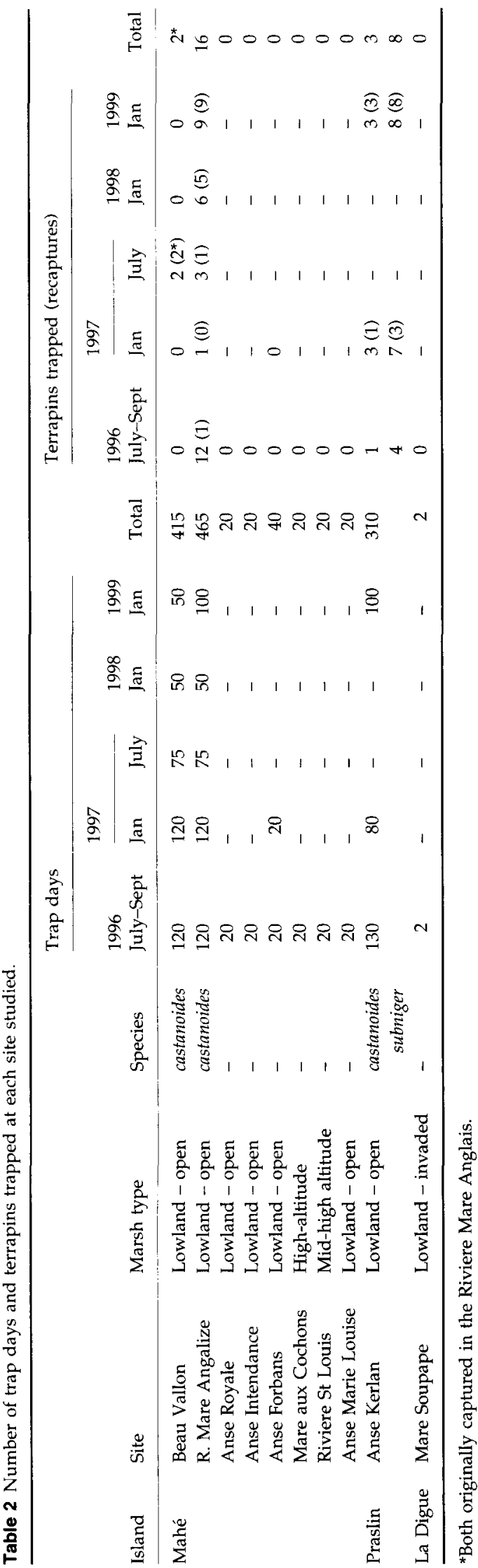

undisturbed, pollution-free sites where trapping was unsuccessful included estuarine Typha javanica reedbed, mangrove swamps, mid- and high-altitude rivers, and high-altitude marshes. Attempts to trap terrapins in the high-altitude marsh at Mare aux Cochons on Mahé and the nearby Rivière Grand St Louis, which have been suggested as possible sites for the little known species $P$. seychellensis ( $R$. Bour, pers. comm.), were unsuccessful. Of the aquatic invertebrates identified during this study only the pond snails Melanoides tuberculata, Gyraulus mauritianus, Physa sp. and Lymnaea natalensis were recorded more than once. These were found to be especially abundant in the Rivière Mare Anglaise on Mahé (Table 1).

We trapped and/or observed terrapins at only six sites on Mahé (Table 1), all of which were lowland marshes. No terrapins were located or reported from mangroves or fast flowing rivers. Apparently suitable habitat (open and seasonal marshes) covers $19.3 \mathrm{ha}$, but terrapin presence was confirmed in only 6.4 ha. The largest $P$. castanoides populations located in this study were in the north of Mahé. The two sites in this area form one marsh system, comprising the Eleocharis reedbed in the Beau Vallon marsh and the woodland river of the Rivière Mare Anglaise. In the former only two terrapins (one male and one female) were caught. Both terrapins had previously been trapped $280 \mathrm{~m}$ away, in the Rivière Mare Anglaise, which supported the main terrapin population. These were the only terrapins to be recaptured more than $50 \mathrm{~m}$ away from the original trapping site, even after 568 days. Of 33 captures (15 individuals and 18 recaptures) in the Beau Vallon Rivière Mare Anglaise marsh system, all dry season captures were in the river, whereas wet season captures were made in the marsh, flooding areas or isolated pools (Table 3 ).

In July 1996, a single male $P$. castanoides was found in the Roche Caiman Bird Sanctuary on Mahé under a pile of reeds ( $T$. javanica), and a second was found crossing open ground nearby in 1997 (J. Mortimer, pers. comm.). The origins of these two individuals were unknown, but because the site is artificial they must either have been

Table 3 Seasonal differences in total number of captures of P. castanoides in the Rivière Mare Anglaise on Mahé over 1996-99.

\begin{tabular}{lllllll}
\hline $\begin{array}{l}\text { Season } \\
\text { (trap days) }\end{array}$ & Sex & River & Marsh & $\begin{array}{l}\text { Flood } \\
\text { area }\end{array}$ & Pool & Total \\
\hline Dry (390) & Male & 9 & 0 & 0 & 0 & 9 \\
& Female & 4 & 0 & 0 & 0 & 4 \\
& Juvenile & 1 & 0 & 0 & 0 & 1 \\
Wet (490) & Male & 0 & 3 & 3 & 0 & 6 \\
& Female & 0 & 1 & 5 & 2 & 8 \\
& Juvenile & 0 & 0 & 0 & 1 & 1 \\
\hline
\end{tabular}


introduced, or have colonized from nearby rivers. No other extant populations were located on Mahé, although reports were received of the presence of $P$. subniger at North-East Point (apparently restricted to a small area of open water; A. Skerrett, pers. comm.) and Anse Forbans (J.-P. Laporte, pers. comm.). Unconfirmed but reliable reports of $P$. castanoides were received from Anse aux Pins, Saint Louis, Anse Aux Poules Bleues and Anse La Mouche (J.-P. Laporte and G. Mourin, pers. comm.).

Terrapins were not found in any marsh on Silhouette and according to residents are not present on the island. On Praslin trapping was unsuccessful in the lowland seasonally flooding forest at Grande Anse (Rivière Nouvelle Decouverte) that lacks potential food items. A report of a terrapin being seen at Baie St Anne in about 1992 (S. de Charmoy Lablache, pers. comm.) was investigated; this area has largely been drained and is now unsuitable. A total of three $P$. castanoides and eight $P$. subniger were trapped in the 1.8 ha Eleocharis dulcis reedbed at Anse Kerlan.

Capture and recapture rates were unfortunately too low to permit estimates of population size using the mark-recapture technique. Of the $16 P$. castanoides caught and marked on Mahé and three $P$. castanoides and $11 P$. subniger caught and marked on Anse Kerlan, all in 1996 and 1997, some were recaptured in 1998 and 1999 , but only one unmarked individual was caught in these last 2 years.

On La Digue at Grand Anse only a small area of marsh appeared suitable and no terrapins were located. During this study, it was found that only 0.1 ha of the Mare Soupape remained free of water lettuce. As a result of this habitat deterioration La Digue no longer supports the important terrapin populations that were recorded previously (Bour, 1984).

The size distribution of trapped terrapins in the Rivière Mare Anglaise on Mahé ( $P$. castanoides) and at Anse Kerlan on Praslin ( $P$. subniger) was biased towards large adults (Fig. 2).

A captive juvenile $P$. subniger was examined that had been found seriously injured, with large pieces of the front and back of the carapace missing. The wounds had healed over and the damaged portions were mending well. A number of small puncture marks identified the cause as an attack by a dog or cat. Either of these species are likely to be major predators of small terrapins on land. All captive $P$. subniger that were originally found on land at Anse Forbans, one of those trapped at Anse Kerlan, and a $P$. castanoides trapped in the Rivière Mare Anglaise, had shell damage with puncture marks and healed breaks in both carapace and plastron indicative of damage caused by dogs after the terrapin had reached adult size. Two male $P$. subniger at Anse
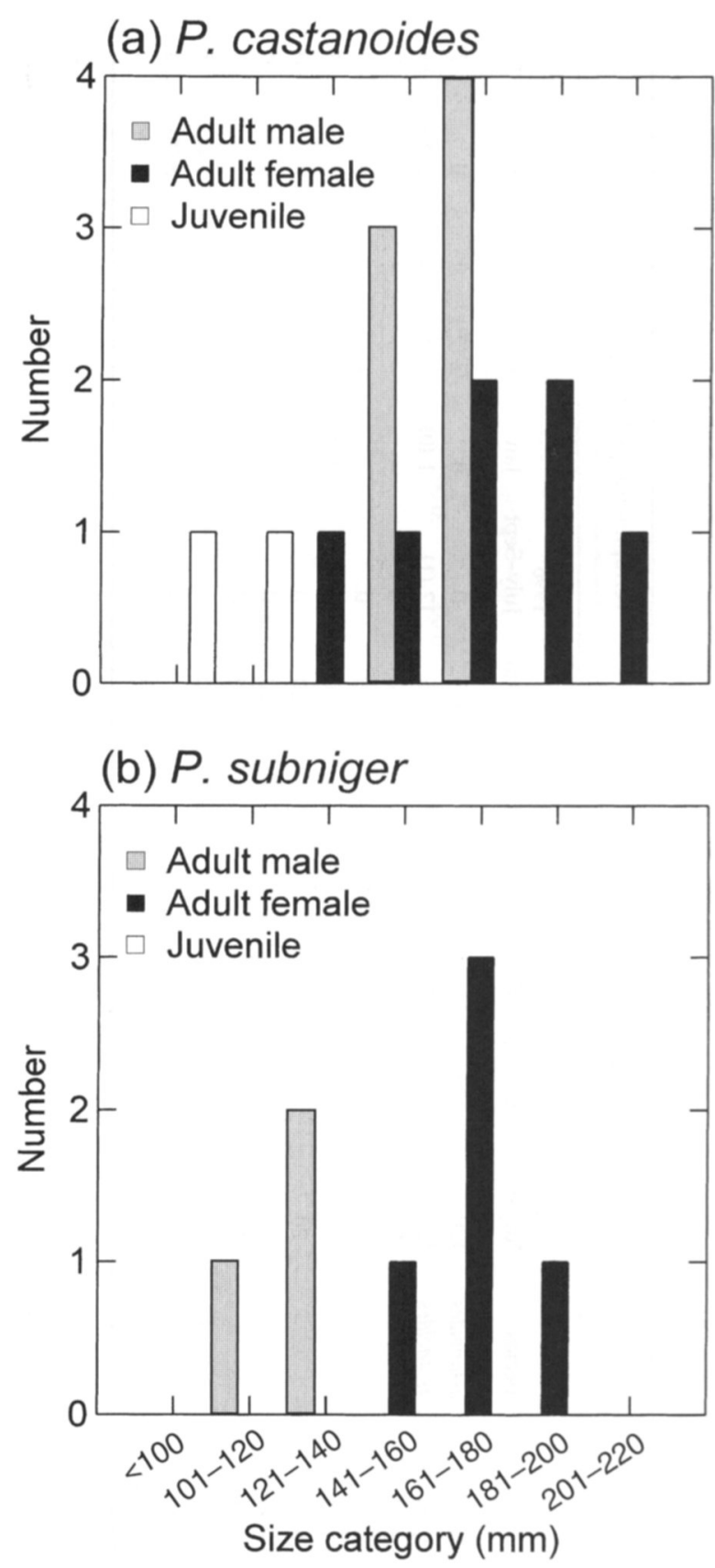

Fig. 2 Size distribution of captured terrapins. (a) Pelusios castanoides (Beau Vallon - Rivière Mare Anglaise, Mahé), (b) Pelusios subniger (Anse Kerlan, Praslin).

Forbans showed extensive shell damage caused by being run over by cars.

\section{Discussion}

The trap data indicates that $P$. castanoides generally occurs in woodland rivers and reed-beds and $P$. subniger in marshes. Both species tend to be restricted to lowland marshes and rivers although two sites (Anse Aux Pins 
and Saint Louis on Mahé) were reported to have terrapins in small marshy areas 50 and $200 \mathrm{~m}$ above sea level, respectively. These have been present for many years and are apparently natural populations, although the marshes are very small in area $(<0.01 \mathrm{ha})$ and the populations must therefore number only a few individuals. Not all lowland marshes appear to be occupied. Of the marshes on Mahé six were found to contain terrapins during this study, and five further marshes were reported to have had terrapins in 1983 (Bour, 1983) but were unoccupied in 1996-1999. The absence of terrapins in at least two of these (Anse Royale and Anse Intendance) may be attributed to recent waterway diversions and high levels of pollution. Of the four marshes not studied one had terrapins in 1964 and another in 1983 (Bour, 1983).

Terrapins appear to have been present on Silhouette in the 1920s (Honegger, 1966), but there have been no subsequent records and the extirpation of the population probably coincided with extensive marsh drainage and forest clearance in the 1930s. The range of marsh habitats and the area of suitable habitat (7.9 ha) is sufficient to have supported both $P$. castanoides and P. subniger.

Of the islands not included in the trapping study six (St. Anne, Cerf, Cousin, Curieuse, Fregate, Grande Soeur and North) have fresh or brackish marshes that could support terrapins. Historical data for terrapin presence on St Anne are limited to a statement that they were present at an unspecified time (G. Lionnet in Bour, 1984) and were reintroduced in the early 1980s (Bour, 1984). In the late 1980s drainage operations led to complete extirpation (L. Chong-Seng, pers. comm.). Cerf supported both $P$. subniger and $P$. castanoides in 1983 (Bour, 1984) and residents (F. Calais and W. Gardner, pers. comm.) report their continued presence in the single permanent marsh (approximately 0.15 ha). Cousin's small permanent marsh $(<0.1$ ha) supports a population of terrapins. These are occasionally seen in other parts of the island (S. Le Maitre, pers. comm.) and are reported to breed ( $\mathrm{R}$. Bresson, pers. comm.). The population is reported to have been introduced from $\mathrm{La}$ Digue in about 1940 (Bour, 1984), and the first record is from 1979 (Bour, 1983). The species has not been identified but from descriptions may be $P$. subniger. A small population of terrapins has been reported from Curieuse (A. Cedras, pers. comm.); from descriptions they may be $P$. subniger, but they are rarely seen. All observations on Curieuse are from the freshwater marsh at Baie Laraie of which approximately 0.2 ha appears to be suitable habitat. $P$. subniger is present on Fregate (Honegger, 1966; Bour, 1984). The small freshwater marsh was originally 1.1 ha in extent, but was recently drained; a replacement marsh area covers 0.2 ha. The population size is not known but anecdotal records indicate that it is low (R. Lucking, pers. comm.). Twelve individuals were seen in 1983 (Bour, 1984), and extensive habitat alterations are believed to have had a major effect on the population (R. Lucking, pers. comm.). Historically terrapins were present in a small marsh area on Aride (Lionnet in Bour, 1983), but this was completely drained early this century and the population is now extinct. There are no records from the other islands but areas of permanent marsh covering less than a hectare exist on North island and Grande Soeur and a small marsh was historically present on Cousine $(<0.1 \mathrm{ha})$. These three marshes have been extensively disturbed and it is probable that most of the native fauna was eliminated in the last century, before any records were published.

Marsh habitat is naturally restricted in Seychelles and so the terrapins will always face the risk of extinction. Their current situation is extremely serious, with very restricted confirmed ranges ( 2.89 and 6.02 ha for $P$. castanoides and $P$. subniger, respectively; Table 1), populations apparently established on only seven islands, and continuing rapid declines in the area and quality of habitat. Using the IUCN Red List Categories (Hilton-Taylor, 2000) both of the Seychelles endemic subspecies should be categorized as Critically Endangered based on criteria A1c (i.e. population reduction (A), estimated to be $>50$ per cent over the last 10 years (1), based on declines in area of occupancy, extent of occurrence and quality of habitat (c)) and B1 and 2c (i.e. area of occupancy less than $0.1 \mathrm{sq} \mathrm{km}$ (B), severely fragmented (1) with continued declines observed (2) in the area, extent and quality of habitat (c)). No evidence could be found of the continued survival of $P$. seychellensis and this species should probably be categorized as Extinct.

The causes of habitat deterioration, and hence population declines, are pollution, drainage, marsh invasion by water lettuce and possibly predation. The effects of pollution are difficult to quantify but it was the only factor that could be identified as a possible cause of the decline in the Anse Royale $P$. castanoides population. Most Seychelles marsh systems suffer from at least some degree of pollution through rubbish dumping, sewage or pesticide run-off. Drainage is a serious problem for the survival of marsh life on Mahé, Praslin and, to a lesser extent, on La Digue. The most significant marsh drainage operation in recent years was at Anse Kerlan on Praslin. The drainage of this exceptional site is indicative of the fact that the profile of marshes in Seychelles needs to be raised.

The damaging impact of water lettuce invasion is demonstrated by its spread over the Mare Soupape on La Digue over a 2-3-year period. This site is well known 
in Seychelles as the 'home of terrapins' (Mare Soupape meaning 'terrapin marsh') with both $P$. castanoides and P. subniger recorded (Peters, 1877; Boulenger, 1889; Bour, 1983). The Mare Soupape covers a large area but water lettuce now forms a complete blanket over the surface of the water, smothering all surface vegetation, shading out submerged vegetation and causing deoxygenation and stagnation of the marsh (Gerlach, 1997b). As a result much of the marsh fauna has been lost. Fish (Oreochromis mossambicus and probably other species) and indigenous pond snails Melanoides tuberculatus were once abundant; both are now restricted to those streams where open water remains. Within marshes dominated by water lettuce only three animal taxa could be located: the introduced pond snail Gyraulus mauritianus, a hydrophilid beetle Helochares melophthalmus and mosquito larvae Aedes albopictus. The first two species were restricted to the oxygenated water film on the underside of the water lettuce leaves. As a result of this, almost all former terrapin habitat has been lost and the displaced terrapin population may face high mortality rates on land because of starvation and predation by cats and dogs. The threat from water lettuce continues to increase as the plant spreads through marshes on Mahé and Praslin.

The threat posed by introduced predators has not been proven but predation by cats, dogs and tenrecs Tenrec ecaudatus (Insectivore) may be contributing to the apparent absence of juvenile terrapins on Mahé and Praslin. It is unlikely that the observed bias towards adults was due to trap avoidance by juveniles because juveniles did enter traps, although on only two occasions, and captive juveniles were as likely as adults to investigate the baits used in this study (J. Gerlach and L. Canning, pers. obs.). Many marshes and rivers have been partially drained and modified, thus reducing suitable nesting areas and concentrating nest predators.

Many of these problems of drainage and resultant terrapin mortality could be solved by protection of wetland habitat, but the current pace of urbanization of lowland areas in Seychelles would make implementation of restrictions on drainage and pollution problematical. The problem of water lettuce invasion is not directly related to development and could be remedied by preventing any further deliberate spreading of the plant, removing any water lettuce attached to objects being moved between marshy areas, and active removal of the existing areas of water lettuce. The Seychelles Division of Environment had been successful in controlling the species at Anse Kerlan. Water lettuce control is urgently required in many areas, especially in the Mare Soupape on La Digue, North-East Point, Rivière Mare Anglaise, Anse Forbans and Anse La Mouche on
Mahé. There are probably many other affected areas, and searches should be made to locate any populations of water lettuce. It is both practical and desirable to eliminate this species from the Seychelles flora.

Until such time as these threats have been addressed there is a need to create secure terrapin populations in areas not threatened by pollution, drainage or water lettuce. Such populations do exist on Cerf, Cousin, Curieuse and Fregate, but these islands provide only a total of 0.6 ha of secure habitat, not all of which is occupied by both species. Marsh restoration and reintroduction of terrapins to Aride, Cousine and North would increase the area to 1.2 ha but would take several years to achieve. A large area of terrapin habitat exists on Silhouette that could support reintroduced populations of both $P$. castanoides and $P$. subniger. A small population could be established in the Roche Caiman Bird Sanctuary on Mahé that has recently been colonized by a single terrapin. The reversal of population declines will require the control of water lettuce, more effective control of marsh drainage and pollution, and the establishment of populations of $P$. castanoides on Silhouette, Aride and North, and P. subniger on Silhouette, Aride and Cousine. A captive breeding project is being implemented by The Nature Protection Trust of Seychelles with the aim of providing juvenile terrapins for these proposed reintroductions. This project recorded its first hatching in February 2000 (Gerlach, 2000).

The need to create new, secure populations should not, however, detract attention from the conservation requirements of the existing populations. It is particularly important to preserve the remaining habitat at Anse Forbans and the Rivière Mare Anglaise on Mahé. These support the most important populations of terrapins remaining in Seychelles and are important sites for flood control for adjacent suburban areas. Any development at these sites should take into account the importance of the remaining riverine and marsh habitat. A similar case for protection of the Mare Soupape on La Digue could be made following water lettuce removal.

\section{Acknowledgements}

The data were collected during a research project sponsored by the British Chelonia Group, James Cadbury, the Environment Trust Fund and Air Seychelles. For accommodation, food, assistance in the field and general assistance we are grateful to R. \& G. Gerlach. Help in field-work was provided by $R$. Gerlach and C. Hollock. Much useful information on terrapin observations was provided by G. d'Uneinville, M. St. Ange and J.-P. Laporte with additional observations from R. Bresson, A. Cedras, M. Kirkpatrick, S. de Charmoy Lablache, R. Lucking, R. Mancienne, P. Matyot, S. Le 
Maitre and G. Mourin. The text was improved with comments from anonymous reviewers and $M$. Fisher.

\section{References}

Boulenger, G.A. (1889) Catalogue of the Chelonians, Rhynchocephalians and Crocodiles in the Brisih Museum (Natural History), London. Trustees of the British Museum, London.

Bour, R. (1983) Trois populations endémiques du genre Pelusios (Reptilia, Chelonii, Pelomedusidae) aux îles Seychelles; relations avec les espèces africaines et malgaches. Bulletin $d u$ Museum nationale d'Histoire naturelle, Paris. Series 4, 5, A, 1, 343-382.

Bour, R. (1984) Taxonomy, history and geography of Seychelles land tortoises and fresh-water turtles. In The Biogeography and Ecology of the Seychelles Islands (ed. D. R. Stoddard), pp. 281-307. Dr W. Junk, The Hague.

Cagle, F.R. (1939) A system of marking turtles for future identification. Copeia, 1939, 170-173.

Gerlach, J. (ed.) (1997a) Seychelles Red Data Book 1997. Nature Protection Trust of Seychelles, Seychelles.

Gerlach, J. (1997b) Water lettuce (Pistia stratiotes) - a new invader. Phelsuma, 5, 75-76.

Gerlach, J. (2000) Current status of Seychelles terrapins. Tortoise and Turtle Newsletter, 2, 11.

Gerlach, J. \& Canning, K.L. (1996) The rediscovery of Pelusios seychellensis. Phelsuma, 4, 68-69.

Hilton-Taylor, C. (Compiler) (2000) 2000 IUCN Red List of Threatened Species. IUCN, Gland, Switzerland and Cambridge, UK.

Honegger, R.E. (1966) Beobachtungen an der Herpetofauna der Seychellen. Salamandra, 2, 21-36.
Legler, J.M. (1960) A simple and inexpensive device for trapping aquatic turtles. Utah Academy of Sciences, Proceedings, 37, 63-66.

Peters, W.C.H. (1877) Sammlung des Hrn. Prof. Dr. K. Möbius auf den Maskarenen und Seychellen. Mitarbeitragen das Academie Wissenschaflich, Berlin, 16, 455-457.

Siebenrock, F. (1906) Schildkröten von Ostafrika und Madagascar. In Reise in Ostafrika in Denjjahren 1903-1905 (ed. A. Voeltzkoe), pp. 1-40. Stuttgart, Germany.

Swingland, I.R. \& Klemens, M.W. (eds) (1989) The Conservation Biology of Tortoises. IUCN, Gland, Switzerland.

Taylor, J.D., Braithwaite, C.J.R., Peake, J.F. \& Arnold, E.N. (1979) Terrestrial faunas and habitats of Aldabra during the late Pleistocene. Philosophical Transactions of the Royal Society of London, B, 286, 47-66.

\section{Biographical sketches}

Justin Gerlach is Scientific Co-ordinator of The Nature Protection Trust of Seychelles and an Affiliated Researcher at the University Museum of Zoology, Cambridge. His interests include evolutionary dynamics and island conservation. Current projects include Indian Ocean Biodiversity Assessment, reviewing the taxonomy and status of the biodiversity of all Seychelles islands.

Laura Canning is currently completing a PhD on theropod dinosaur systematics at the Department of Geology, University of Cambridge. She has interests in reptile ecology and evolution and has collaborated on research on the Seychelles fauna, including crocodiles and tortoises. 